DE-FG03-96ER212194

PI: K.J. Danna

Time period covered for progress report: 6/15/96-3/10/97

a

OVERVIEW

JUN 091997

DOE/ER/12194-T/

The goal of this project is to facilitate copersion df plant biomass to usable energy by developing transgenic plants that express genes for microbial cellulases, which can be activated after harvest of the plants. In particular, we want to determine the feasibility of targeting an endoglucanase and a cellobiohydrolase to the plant apoplast (cell wall milieu). The apoplast not only contains cellulose, the substrate for the enzymes, but also can tolerate large amounts of foreign protein. To avoid detrimental effects of cellulase expression in plants, we have chosen enzymes with high temperature optima; the genes for these enzymes are from thermophilic organisms that can use cellulose as a sole energy source.

During the first nine months of our grant period, we have focused on developing the tools necessary for expressing cellulase genes in plants (specific objectives 1-3 of our proposal): plasmids that contain cellulase genes engineered for expression in plants; cellulase assays; and transfection of plant protoplasts for transient expression assays and for selection of transformed cells. During the next three months, we will begin testing the expression of the cellulase genes in protoplasts and will transfer the genes to binary vectors for Agrobacteriummediated transformation of Arabidopsis thaliana, which we will pursue during years 2 and 3 . Our results and findings are described below, and details are presented in Appendices I-IV.

\title{
CONSTRUCTION OF PLASMIDS
}

Starting material (Appendix I): The plasmids we construct for targeting cellulases to the plant apoplast must contain the cellulase gene; a promoter at the $5^{\prime}$ end of the gene for transcription in plants; a plant signal peptide at the amino terminus of the protein to direct the enzymes to the endoplasmic reticulum (ER) for eventual secretion; a polyA signal at the $3^{\prime}$ end of the gene to ensure proper mRNA processing; and as a desirable feature, a translational enhancer upstream of the gene to increase levels of expression. We have chosen the Cauliflower Mosaic Virus 35S promoter (CaMV35S) for constitutive expression and the Arabidopsis thaliana SAG12 promoter for expression during senescence (if needed); the tobacco Pr1a signal peptide; the nos gene poly-A signal; and the tobacco mosaic virus $\Omega$ enhancer. The basic expression cassette has this arrangement:

\section{plant promoter - $\Omega$ - Pr1a - cellulase gene - polyA signal}

In addition, we need to use three other elements: a reporter gene to monitor function of our regulatory elements; a selectable marker (kanamycin resistance) for obtaining transgenic plant cells in culture; and a binary vector for Agrobacterium-mediated transformation of plants. We will use the GUS reporter gene and will improve our original strategy by using a second reporter, the green fluorescent protein (GFP). Many of these elements are available on preexisting plasmids, which are shown in Appendix I. We have obtained small samples of each DNA, transfected them into E. coli to make frozen cell stocks, prepared working stocks of DNA, and verified the identity of each by diagnostic restriction enzyme analysis.

\section{DSTRIBUTION OF THIS DOCUMENT IS UNLIMITED}




\section{DISCLAIMER}

This report was prepared as an account of work sponsored by an agency of the United States Government. Neither the United States Government nor any agency thereof, nor any of their employees, make any warranty, express or implied, or assumes any legal liability or responsibility for the accuracy, completeness, or usefulness of any information, apparatus, product, or process disclosed, or represents that its use would not infringe privately owned rights. Reference herein to any specific commercial product, process, or service by trade name, trademark, manufacturer, or otherwise does not necessarily constitute or imply its endorsement, recommendation, or favoring by the United States Government or any agency thereof. The views and opinions of authors expressed herein do not necessarily state or reflect those of the United States Government or any agency thereof. 


\section{DISCLAMMER}

Portions of this document may be illegible in electronic image products. Images are produced from the best available original document. 
Construction of plasmids for expression of cellulases in protoplasts (Appendix II): We isolated the gene for the endoglucanase E1 by PCR amplification from genomic DNA of Acidothermus cellulolyticus and cloned the product into E. coli vector pSL301. The gene is expressed in E. coli, and the enzyme is functional. We built the Pr1a signal peptide by ligating together seven overlapping synthetic oligonucleotides and then inserted the sequence into plasmid pJD301 in place of the luciferase gene to obtain plasmid pMZ215 (see Appendices I and II for description of plasmids and Appendix III for a diagram of our cloning strategy). We then inserted the functional $\mathrm{E} 1$ coding region into $\mathrm{pMZ215}$ to obtain plasmid $\mathrm{pMZ228}$, which is now ready for transfection into protoplasts. Expression of this plasmid in plant cells should result in the secretion of E1 into the apoplast. We will test whether such cells are viable.

Construction of the cellobiohydrolase $\mathrm{CBHI}$ expression plasmid is now about $95 \%$ completed. Our strategy, shown in Appendix IV, is more complex because the $\mathrm{CBH}$ gene contains sites for many restriction enzymes, thus precluding a simple transfer step. Because we cannot test this gene for function in $E$. coli, we must verify its integrity by nucleotide sequencing. This step is important because the enzymes used to produce the original cDNA clone and to amplify the gene during PCR amplification can introduce errors. The sequence of one PCR-amplified clone of $\mathrm{CBHI}$ indicates a single base change that would cause a proline to leucine mutation (relative to the published sequence). We are currently determining whether this mutation is present in the original $\mathrm{CBHI}$ clone; if so we plan to restore the correct sequence through site-directed mutagenesis.

Small plasmid for selecting transformants: We have transferred the kan-r gene from $\mathrm{pBI} 121$ (a large plasmid) into the smaller vector $\mathrm{pFG11A}$, inserting it between the promoter and polyA signal. We will use this plasmid, pNP19, in cotransformation experiments with protoplasts to select for transformed cells that will also contain the cellulase expression plasmids. This plasmid will be useful to others in the field.

Testing Cauliflower Mosaic Virus $35 S$ promoter for activity in E. coli: The CaMV35S promoter has high activity in plant cells but no reported activity in E. coli. Because all of the genes we are cloning for expression in plant cells are linked to the CaMV35S promoter, not to an $E$. coli promoter, we did not expect to be able to test for function of the genes until we express them in plants. Thus the only way to know that the cloned genes have no mutations is to determine the nucleotide sequence. If the CaMV35S promoter functions in $E$. coli as well as in plants, we (and others) could test plasmids using functional assays for the genes and could dispense with nucleotide sequencing in most cases.

Our plasmid pNP19 contains an ampicillin gene with an E. coli promoter and a kanamycin gene linked to the CaMV35S promoter. When we constructed the plasmid we selected the original clone on medium containing ampicillin. To test whether the CaMV35S promoter functions in $E$. coli, we plated the cells on medium containing kanamycin. One candidate clone that contains plasmid DNA with an insert of the expected size is resistant to kanamycin, suggesting that the plant promoter is indeed expressed in E. coli. We will follow up on this observation because of the significance and usefulness of the finding. 
Development of an alternate reporter gene: To monitor the effectiveness of our expression cassettes and to optimize protoplast transfection protocols, we want to use as a reporter a modified green fluorescent protein (GFP) optimized for plant expression. We have obtained the parent plasmid and have designed PCR primers for transferring the gene to our expression cassettes. The advantage of this reporter are that it provides a very easy, sensitive assay for expression in individual living cells in "real time," rather than in plant extracts. Thus we can easily determine through microscopy whether this protein is localized in the apoplast as a test of our expression cassettes. This reporter will also make it easy to determine what percentage of protoplasts is transfected with DNA in experiments designed to optimize transfection efficiency.

Improvement of binary vectors: The two readily available binary vectors, pOCA28 and pBI121 (Appendix I), which we need for obtaining transgenic Arabidopsis thaliana plants, have a very small number of cloning sites for inserting our cellulase expression cassettes. We are improving these vectors by adding a polylinker that contains sites for 45 enzymes, including the rare-cutter, Notl, and will determine which sites are unique and therefore suitable for cloning. These improved vectors will be generally useful to other researchers in the field.

\section{CELLULASE ASSAYS}

To detect expression of cellulases in transfected plant cells, we are pursuing two kinds of assay: Western blots to detect $\mathrm{CBHI}$ and cellulase assays to detect either $\mathrm{E} 1 \mathrm{\text {or }} \mathrm{CBH}$. We have obtained purified $\mathrm{CBHI}$ and antibodies against this protein (a gift from $\mathrm{Dr}$. Steve Thomas) to use for controls in Western blots. We have set up a gel diffusion assay to measure endoglucanase activity, based on the fact that Congo Red stains the substrate carboxymethylcellulose, and we have begun experiments to measure relative activity of cloned $\mathrm{E} 1$ at various temperatures. These experiments are still in progress.

\section{TRANSFECTION OF PROTOPLASTS}

To determine whether our cellulase expression cassettes are effective and whether plant cells can regenerate walls when cellulases are targeted to the apoplast, we have established a plant cell culture system to use for transient expression assays and for selection of transformed cells. We are using the tobacco BY2 cell line (a kind gift from R. Scyr) because it is easy to maintain and protoplasts derived from it are easy to transfect. We have completed pilot experiments to compare different transfection methods and plating regimes and to determine the optimal time frame for detecting transiently expressed proteins.

We have compared electroporation and polyethylene glycol (PEG)-mediated transfection of BY2 protoplasts, using expression of the GUS reporter gene as an assay. Although both methods result in GUS expression, survival of protoplasts proved higher with PEG, and this method will be easier to scale up. Using PEG-mediated transfection, we have determined that transient GUS expression peaks at about 40-48 hours after addition of DNA. Therefore, when we monitor cellulase expression, we will conduct the time course to at least $50 \mathrm{hr}$. 
DE-FG03-96ER12194

PI: K.J. Danna
Controlled Production of Cellulases in Plants for Biomass Conversion Time period covered for progress report: 6/15/96-3/10/97

We have tested alginate as a solid medium for plating transfected BY2 protoplasts: though this method has been used for a limited number of cell types, it has not yet been used for BY2 cells, to our knowledge. Alginate has several advantages: it is strong, clear, inexpensive, and easy to handle once polymerized; it does not require heating; and it readily depolymerizes upon exposure to chelating agents. In our hands, BY2 protoplasts embedded in alginate grow rapidly, regenerate walls quickly, and grown into callus (needed for selection of permanently transformed cells). Lastly, we determined that a kanamycin concentration of 50 micrograms per $\mathrm{ml}$ or greater in the medium is sufficient to kill BY2 cells plated in alginate. We are now prepared to test the cellulase expression plasmids in BY2 celis in transient expression assays. Moreover, we can select for kanamycin resistant colonies resulting from transfection of our kan-r plasmid together with the cellulase plasmids in cotransformation experiments.

\section{GOALS FOR THE LAST THREE MONTHS OF YEAR 1}

- complete construction of plasmids pMZ-CBHI, pMZ-GFP, pMZ-SAGs, pOCA28-SL, and $\mathrm{pB} \mid 121-\mathrm{SL}$ and if necessary restore wild-type sequence in CBHI gene (plasmid pB210)

- transfer expression cassettes into improved binary vectors for Agrobacterium-mediated transformation of Arabidopsis thaliana

- follow up on preliminary results that suggest activity of the CaMV35S promoter in E. coli

- determine cotransformation frequency of pNP19 and reporter plasmid (either GUS or GFP)

- transfect protoplasts with cellulase and GFP expression cassettes and monitor transient expression of the genes

- transfect protoplasts with cellulase and GFP expression cassettes together with kan-r plasmid and set up selection for transformed cells

- continue experiments to determine E1 cellulase activity at various temperatures, using quantitative assays

- prepare for transformation of Arabidopsis thaliana with cellulase expression cassettes by growing up stocks of plants and performing a control transformation with pBI121 
DE-FG03-96ER12194

PI: K.J. Danna
Controlled Production of Cellulases in Plants for Biomass Conversion Time period covered for progress report: 6/15/96-3/10/97

\section{APPENDIX I: STARTING MATERIAL FOR CONSTRUCTION OF PLASMIDS}

After obtaining each of these plasmids in E. coli, we prepared frozen stocks and DNA for use in our experiments. In addition, we performed diagnostic restriction digests to verify each plasmid's identity.

\begin{tabular}{|c|c|c|}
\hline NAME & FEATURES & USE(S) \\
\hline pBSII SK (+) & $\begin{array}{l}\text { Standard E. coli cloning vector for } \\
\text { blue/white colony screening }\end{array}$ & $\begin{array}{l}\text { Construction of cassettes for 3'polyA signal; } \\
35 \mathrm{~S} \text { promoter }+\Omega+/ \text { - Pr1a; and CBHI } \\
\text { expression }\end{array}$ \\
\hline pSL301 & $\begin{array}{l}\text { E. coli cloning vector with extensive } \\
\text { polylinker ( } 51 \text { enzyme sites) }\end{array}$ & $\begin{array}{l}\text { - Cloning E1 gene } \\
\text { - Source of large polylinker for improved } \\
\text { binary vectors }\end{array}$ \\
\hline $\mathrm{pB} \mid 221.2$ & $\begin{array}{l}\text { GUS reporter with CaMV 35S promoter } \\
\text { and nos3' polyA signal in pUC19 (gift } \\
\text { from M. Bevans) }\end{array}$ & $\begin{array}{l}\text { Small control plasmid for transient expression } \\
\text { assays in plant protoplasts }\end{array}$ \\
\hline pBI121 & $\begin{array}{l}\text { 12-kb plasmid containing kan-r and } \\
\text { GUS genes with plant promoters and } \\
\text { polyA signals flanked by Ti LB and RB } \\
\text { sequences (gift from M. Bevans) }\end{array}$ & $\begin{array}{l}\text { - Binary vector for Agrobacterium-mediated } \\
\text { transformation } \\
\text { - Source of kan-r gene in plasmid used for } \\
\text { cotransformation of protoplasts } \\
\text { - Starting DNA for improved binary vector } \\
\text { (replacement of GUS with polylinker) }\end{array}$ \\
\hline POCA28 & $\begin{array}{l}\text { High copy, 23-kb plasmid with kan-r, } \\
\text { COS site, and Ti LB and RB; spec and } \\
\text { str selection for both E.coli and } \\
\text { Agrobacterium (gift from N. Olszewski) }\end{array}$ & $\begin{array}{l}\text { - Binary vector for Agrobacterium-mediated } \\
\text { transformation } \\
\text { - Starting DNA for improved binary vector } \\
\text { (addition of polylinker) }\end{array}$ \\
\hline pFG11A & $\begin{array}{l}\text { pUC19 containing 2XCaMV35S } \\
\text { promoter, IBVM, GUS, and CaMV polyA } \\
\text { signal (gift from A. Staehelin) }\end{array}$ & $\begin{array}{l}\text { Parent plasmid for construction of small kan-r } \\
\text { expression cassette for cotransformation of } \\
\text { protoplasts (IBVM and GUS replaced with } \\
\text { kan-r gene from pBI121) }\end{array}$ \\
\hline $\mathrm{pB} 210$ & $\begin{array}{l}\text { Contains cDNA of CBHI from T. reesei; } \\
\text { not yet sequenced to verify integrity of } \\
\text { gene (gift from S. Thomas) }\end{array}$ & $\begin{array}{l}\text { Template for PCR amplification to construct } \\
\text { CBHI expression cassettes }\end{array}$ \\
\hline pSG506 & $\begin{array}{l}\text { Contains SAG12 senescence promoter } \\
\text { (gift from R. Amasino and S. Gan) }\end{array}$ & $\begin{array}{l}\text { Source of SAG12 promoter for expression } \\
\text { cassettes }\end{array}$ \\
\hline pBIN-m-gfp5-ER & $\begin{array}{l}\text { Contains gene for green fluorescent } \\
\text { protein optimized for expression in plant } \\
\text { cells (gift from J. Haseloff) }\end{array}$ & $\begin{array}{l}\text { - Template for PCR amplification of GFP to be } \\
\text { used as reporter gene for Pr1a signal } \\
\text { peptide and promoter function } \\
\text { - Reporter gene for optimizing transformation } \\
\text { of protoplasts }\end{array}$ \\
\hline pJD301 & $\begin{array}{l}\text { pUC18 containing luciferase reporter } \\
\text { with CaMV } 35 \text { S promoter, } \Omega \\
\text { translational enhancer, and nos3' poly } \\
\text { A signal }\end{array}$ & $\begin{array}{l}\text { - Source of } 35 S / \Omega \text { for cassette } \\
\text { - Template for PCR amplification of nos3' } \\
\text { polyA signal for cassette } \\
\text { - Parent plasmid for insertion of Pr1a signal } \\
\text { and E1 gene }\end{array}$ \\
\hline
\end{tabular}

CaMV35S: constitutive plant promoter

$\Omega$ : translational enhancer sequence for plants nos3' and CaMV-polyA: plant polyA signals

Pr1a: signal peptide targeting proteins for secretion 
DE-FG03-96ER12194

Pl: K.J. Danna
Controlled Production of Cellulases in Plants for Biomass Conversion Time period covered for progress report: $6 / 15 / 96-3 / 10 / 97$

APPENDIX II: PLASMIDS WE HAVE CONSTRUCTED

\begin{tabular}{|c|c|c|}
\hline NAME & FEATURES & STATUS \\
\hline $\mathrm{pE1}$ & $\begin{array}{l}\text { - Complete gene for endoglucanase E1, } \\
\text { including endogenous promoter and signal } \\
\text { - PCR amplified from genomic DNA of } \\
\text { Acidothermus cellulolyticus and cloned into } \\
\text { E. coli vector pSL301 }\end{array}$ & $\begin{array}{l}\text { Cloning is completed. Cloned gene } \\
\text { is functional, producing active, } \\
\text { secreted enzyme in host } E \text {. coli. } \\
\text { Therefore, sequencing is not } \\
\text { necessary. }\end{array}$ \\
\hline pMZ222 & $\begin{array}{l}\text { Pr1a signal peptide constructed by ligation of } \\
\text { overlapping oligonucleotides and cloned into } \\
\text { E. coli pBS vector }\end{array}$ & $\begin{array}{l}\text { Cloning is completed. Pr1a } \\
\text { cassette is available for transfer to } \\
\text { other plasmids. }\end{array}$ \\
\hline pMZ215 & $\begin{array}{l}\text { - Pr1a signal peptide cloned into pJD301 in } \\
\text { place of luciferase reporter gene (Fig. 1) } \\
\text { - Contains CaMV35S, } \Omega \text {, and nos 3' } \\
\text { - Contains Sacl site for insertion of E1 (or } \\
\text { other) gene in frame with Pr1a }\end{array}$ & $\begin{array}{l}\text { Cloning is completed. Nucleotide } \\
\text { sequencing is completed. DNA is } \\
\text { available for insertion of coding } \\
\text { region of proteins to be expressed } \\
\text { in plant cells and targeted to the } \\
\text { apoplast. }\end{array}$ \\
\hline pMZ228 & $\begin{array}{l}\text { E1 coding region inserted into pMZ215 in } \\
\text { frame with Pr1a }\end{array}$ & $\begin{array}{l}\text { Cloning is completed and plasmid } \\
\text { is ready for transfection of } \\
\text { protoplasts. }\end{array}$ \\
\hline pKR1 & $\begin{array}{l}\text { - CaMV35S and } \Omega \text { subcloned from pJD301 } \\
\text { into pBS } \\
\text { - Cassette to be placed upstream of genes } \\
\text { for expression in plant cells } \\
\text { - Cassette flanked by multiple restriction } \\
\text { enzyme cleavage sites for easy transfer }\end{array}$ & $\begin{array}{l}\text { Cloning is completed. } \\
\text { Sequencing is not completed. }\end{array}$ \\
\hline $\mathrm{pMZ-CBHI}$ & $\begin{array}{l}\text { Contains CBHI coding region with regulatory } \\
\text { elements for expression in plant cells and } \\
\text { targeting to apoplast }\end{array}$ & $\begin{array}{l}\text { Cloning is } 95 \% \text { completed (Fig. } 2 \text { ). } \\
\text { When verified, DNA will be ready } \\
\text { for transfection of protoplasts. }\end{array}$ \\
\hline pMZ-GFP & $\begin{array}{l}\text { - Contains GFP reporter inserted between } \\
\text { Pr1a and nos3' of pMZ215 } \\
\text { - Used to monitor effectiveness of Pr1a in } \\
\text { targeting proteins to the apoplast }\end{array}$ & $\begin{array}{l}\text { In progress: primers for PCR } \\
\text { amplification are designed. }\end{array}$ \\
\hline pMZ-SAG & $\begin{array}{l}\text { Contains SAG12 senescence promoter in } \\
\text { place of } 35 \mathrm{~S}\end{array}$ & In progress: design stage. \\
\hline pNP19 & $\begin{array}{l}\text { - Small plasmid containing kan-r gene from } \\
\text { pBI121 equipped with two copies of } \\
\text { CaMV35S and a CaMV-polyA signal } \\
\text { - Used for selection in cotransformation of } \\
\text { protoplasts with cellulase constructs }\end{array}$ & $\begin{array}{l}\text { Cloning is completed. } \\
\text { Preliminary results indicate that the } \\
\text { cloned gene is functional. } \\
\text { Sequencing will not be necessary. }\end{array}$ \\
\hline POCA28-SL & $\begin{array}{l}\text { - Derivative of pOCA28 containing super- } \\
\text { linker sequence to provide cloning sites } \\
\text { - Binary vector for Agrobacterium-mediated } \\
\text { transformation of plants }\end{array}$ & $\begin{array}{l}\text { In progress: starting DNAs are } \\
\text { prepared and restriction enzyme } \\
\text { digestions are completed. }\end{array}$ \\
\hline pBI121-SL & $\begin{array}{l}\text { - Derivative of pBI121 containing superlinker } \\
\text { in place of GUS gene } \\
\text { - Binary vector for Agrobacterium-mediated } \\
\text { transformation of plants }\end{array}$ & $\begin{array}{l}\text { In progress: starting DNAs are } \\
\text { prepared and restriction enzyme } \\
\text { digestions are completed. }\end{array}$ \\
\hline
\end{tabular}


- DE-FG03-96ER12194

PI: K.J. Danna

\section{APPENDIX III: SCHEME FOR BUILDING E1 EXPRESSION PLASMID pMZ228}

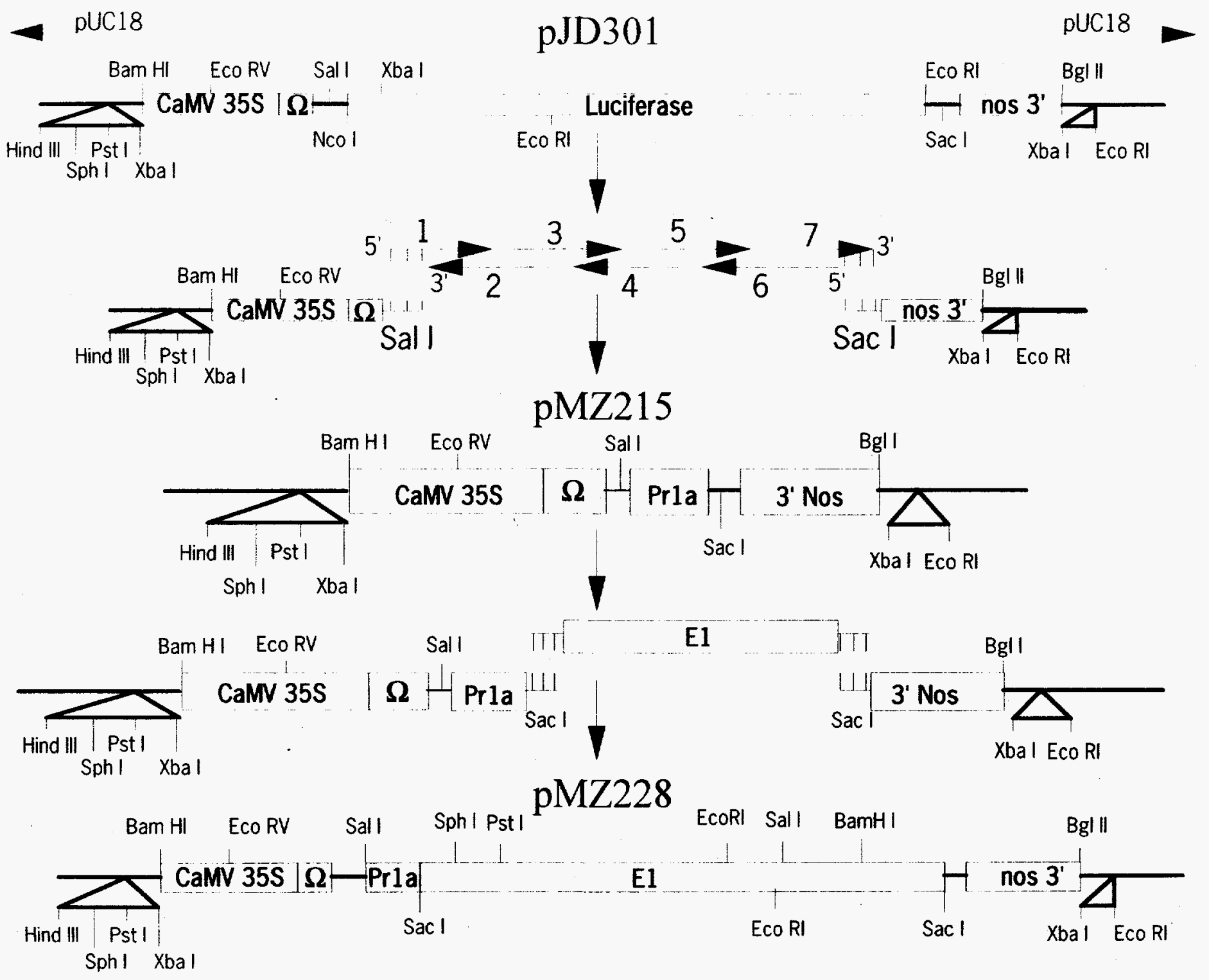




\section{APPENDIX IV: SCHEME FOR BUILDING CBHI EXPRESSION PLASMID PMZ-CBHI}

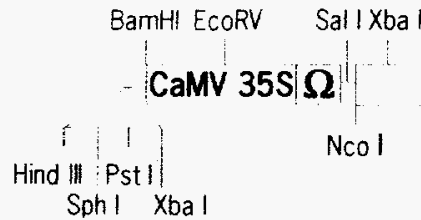

1. Cut pJD301 with BamHI and Sal I to liberate CaMV 35S/Omega and subclone into BamHI/Sal I digested pBluescript II SK (+)

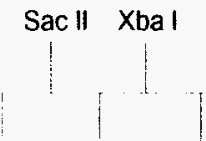

Sac I Not I Spe I
BamH

CaMv 35s $\Omega$

Sal I Xhol KpnI

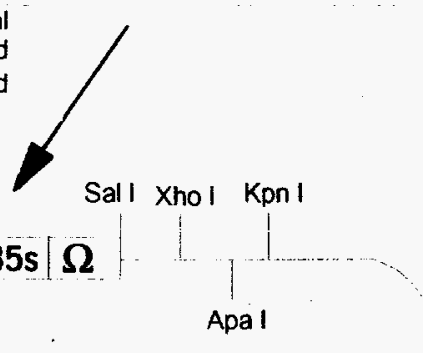<smiles>[198Pb]</smiles>

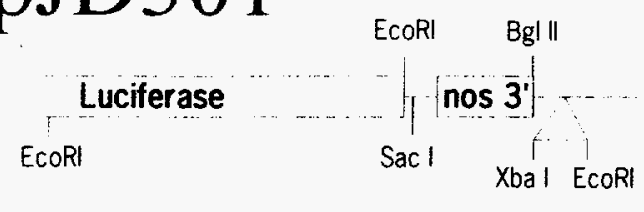

pUC18
5. PCR nos $3^{\prime}$ with Kpn I sites fabricated into the primers to allow for subcloning into $\mathrm{Kpn}$ ! site $3^{\prime}$ of $\mathrm{CBH}$.

pBluescript II SK (+) Digest with Sal I and Xho I 5. Pr1a Xhol 5 Sall

2. Ligation of seven overlapping oligos to generate the Pr1a apoplast signal which will be cloned into Sal I and Xho I digested pBluescript containing the CaMV $35 \mathrm{~S}$ and Omega

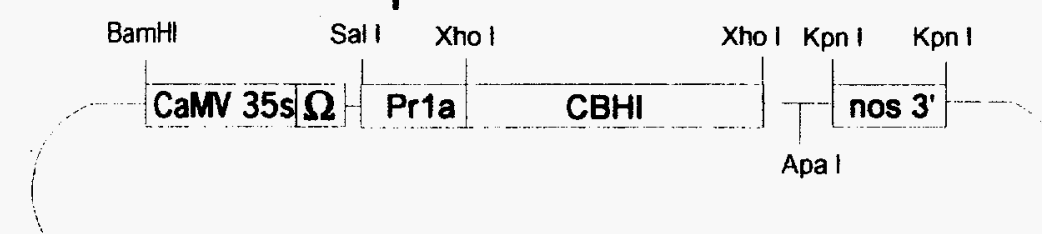

pBluescript II SK (+)

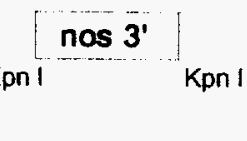

pMZ-CBHI

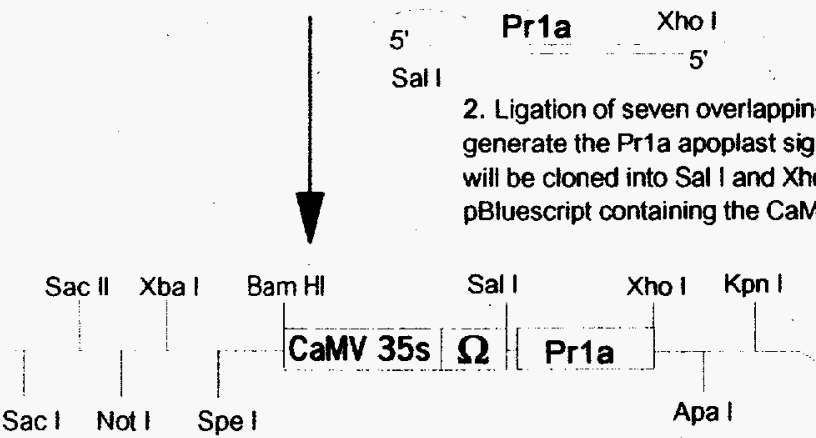

pBluescript II SK (+)

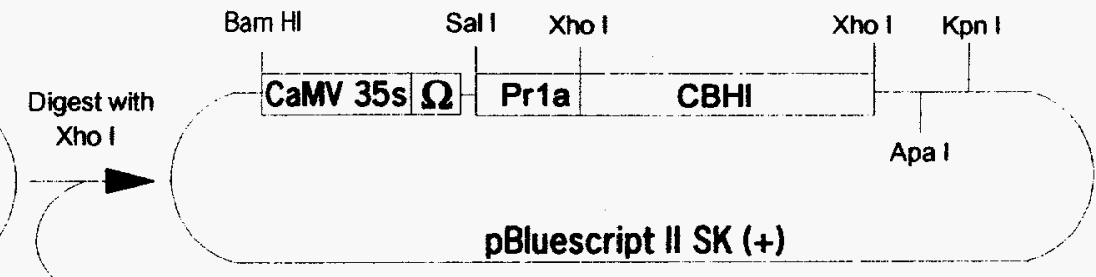

3. PCR of CBHI with Xho I sites fabricated into primers to allow for cloning in-frame 3' of the Pr1a signal peptide

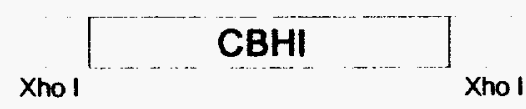

